\title{
Crustal movement of Antarctica and Syowa Station based on GPS measurements
}

\author{
Mako Ohzono $^{1}$, Takao Tabei ${ }^{2}$, Koichiro Doi $^{3}$, Kazuo Shibuya $^{3}$, and Takeshi Sagiya ${ }^{1}$ \\ ${ }^{1}$ Graduate School of Environmental Studies, Nagoya University, Furo-cho, Chikusa-ku, Nagoya 464-8602, Japan \\ ${ }^{2}$ Department of Natural Environmental Science, Kochi University, Akebono-cho 2-5-1, Kochi 780-8520, Japan \\ ${ }^{3}$ National Institute of Polar Research, 9-10, Kaga 1-chome, Itabashi-ku, Tokyo 173-8515, Japan
}

(Received June 6, 2005; Revised March 22, 2006; Accepted March 23, 2006; Online published July 26, 2006)

\begin{abstract}
In Antarctica, sea level rise and crustal uplift have occurred due to ice sheet melting and mantle response since the Last Glacial Maximum (LGM). The International GNSS Service (IGS) provides continuous data at nine sites on the Antarctic plate, and we analyzed data obtained from these sites between 1998 and 2003. Additional data were acquired by campaign observations around Syowa Station carried out by the Japanese Antarctic Research Expedition (JARE). Five sites around Syowa Station have been repeatedly occupied since 1998. Our analysis of the IGS data demonstrates that the Antarctic continent behaves as a rigid plate. Vertical components indicate an uplift of about 1.3-7.0 mm/year at almost all sites, which are attributed to the postglacial rebound. However, some observed velocities disagree with the predictions of glacial isostatic adjustment (GIA) models. It will be necessary to incorporate our results into the modeling of ice sheet melting. Around Syowa Station, the campaign GPS result is basically consistent with the IGS data analysis, thereby demonstrating that GPS observations properly represent the ongoing crustal movement around Syowa Station. However, the GPS results show some disagreement with the VLBI observations; this discrepancy will need to be sorted out using local tie observations that should be carried out in the near future.
\end{abstract}

Key words: GPS, Antarctica, Syowa Station, crustal movement, plate motion.

\section{Introduction}

The melting of large polar ice sheets has caused eustatic sea level rise and isostatic crustal uplift since the Last Glacial Maximum (LGM). Various glacial isostatic adjustment (GIA) models have been proposed to reproduce geologically recorded temporal variations in relative sea level by assuming the melting history of the ice sheets (e.g. Wu and Peltier, 1983; Nakada and Lambeck, 1988, 1989; Tushingham and Peltier, 1991; Peltier, 1994; Nakada et al., 2000). In all of these models the melting history of the Antarctic ice sheet was based on the CLIMAP reconstruction (Hughes et al., 1981; Stuiver et al., 1981), and the thickness of the contemporary ice sheet was assumed after Drewry (1982). In 1991 Denton et al. proposed a new ice sheet model based on isotope data of ${ }^{10} \mathrm{Be}$ and $\delta^{18} \mathrm{O}$ as well as detailed studies of the moraine drift. Using this model as a basis, James and Ivins (1998) constructed a new model-D91-which they subsequently used to predict several geophysical observables such as crustal uplift and gravity anomaly.

Contemporary geodetic observation provides additional constraints on models of ice sheet melting history. With space geodetic techniques such as Very Long Baseline Interferometry (VLBI) and Global Positioning System (GPS), we are able to measure a displacement rate of geodetic mon-

Copyright (c) The Society of Geomagnetism and Earth, Planetary and Space Sciences (SGEPSS); The Seismological Society of Japan; The Volcanological Society of Japan; The Geodetic Society of Japan; The Japanese Society for Planetary Sciences; TERRAPUB uments with a precision of less than $1 \mathrm{~mm} / \mathrm{year}$, and we can subsequently compare these observed values with those predicted from ice sheet and response models of the polar region. Fukuzaki et al. (2005) reported results of VLBI observations at Showa Station $\left(39.6^{\circ} \mathrm{E}, 69.0^{\circ} \mathrm{S}\right.$, Fig. 1) and discussed the plate motion model as well as the postglacial rebound. In addition, there are nine continuous GPS sites on the Antarctic continent as a part of a monitoring network of the International GNSS Service (IGS). Some initial GPS observations have resulted in an estimation of the Antarctic plate motion; they were also compared with contemporary global plate motion models (see Yamada et al., 1998; Bouin and Vigny, 2000; Dietrich et al., 2001, 2004; Prawirodirdjo and Bock, 2004) and GIA models (Raymond et al., 2004).

We report here our analysis of two sets of bedrock GPS data. One set consists of continuous observation data collected at nine IGS sites from 1998 to 2003. We analyzed data from a larger number of IGS sites and for a longer time span than has been reported in previous studies in order to realize a more accurate estimate of motion at GPS sites. The second set of GPS data is the result of campaignmode GPS observations that were carried out around Syowa Station as a part of the Japanese Antarctic Research Expedition (JARE) program. In this campaign, five sites have been repeatedly occupied since 1998 . This data set provides information on the local crustal deformation around Syowa Station and is also useful in verifying that the SYOG site, an IGS site located at Syowa Station, properly represents crustal movement in the surrounding area. Based on these 


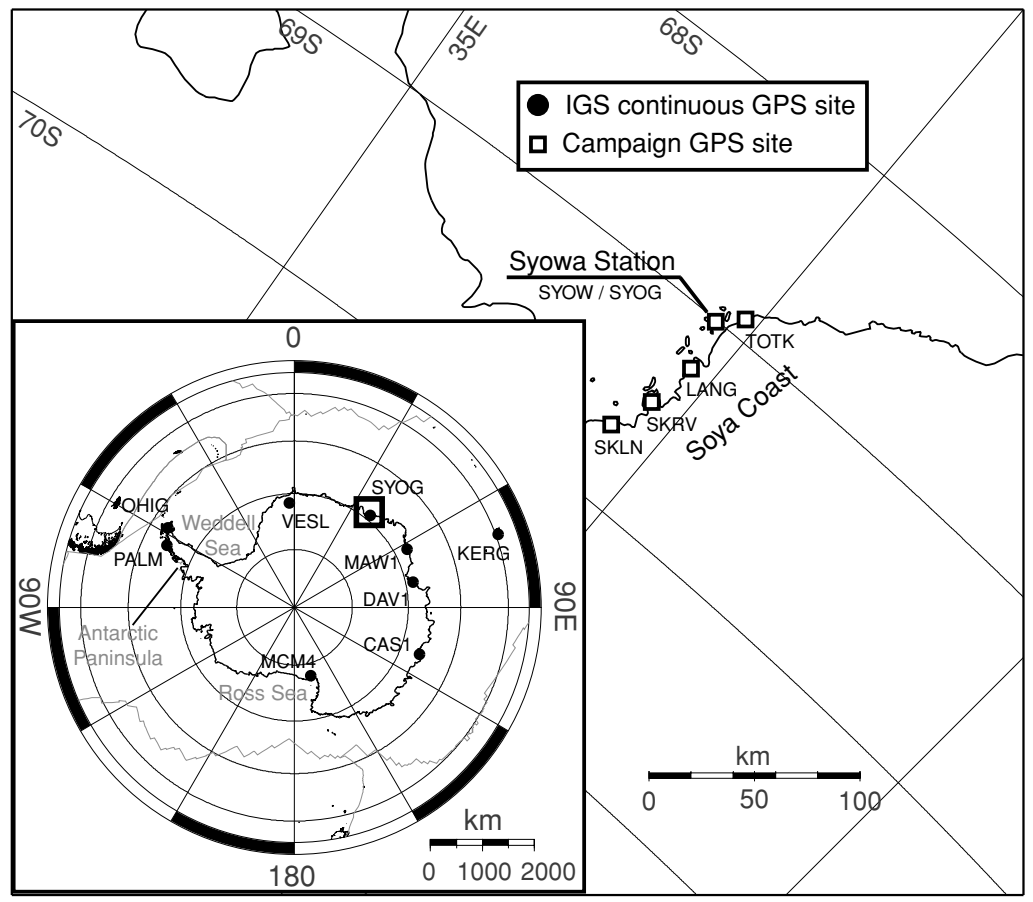

Fig. 1. Location of Syowa Station, Antarctica. Five campaign GPS observation sites have been constructed near Syowa Station. Syowa Station has both IGS continuous site SYOG and campaign site SYOW.

results, we discuss the plate motion of the Antarctic continent and postglacial rebound models.

\section{Campaign GPS Observations around Syowa Station}

In order to monitor crustal deformation around Syowa Station, campaign-mode GPS observations have been conducted as a part of JARE program since 1998. We established five sites, Tottuki Point (TOTK), Syowa Station (SYOW), Langhovde (LANG), Skarvsnes (SKRV), and Skallen (SKLN). An anchor bolt was buried in a bedrock outcrop at each site. These five campaign sites are located along the Sôya Coast, spanning a total length of about 90 km (Fig. 1), with SYOW located only $18 \mathrm{~m}$ from the SYOG, an IGS site located at Syowa Station.

We deployed Ashtech Z-Surveyor receivers and Dorne Margolin choke ring antennas without radome for our campaign observations. Pseudo-range as well as carrier phase data were sampled every $30 \mathrm{~s}$ with an elevation mask of $15^{\circ}$.

The campaign observations have been repeated a few times every year since 1998. In each campaign, each site was occupied for a few days, while SYOW was occupied for a longer time so as to be used as a reference site. Available data from these campaigns are summarized in Table 1. Since this is a campaign observation, the height of the GPS antenna changed from one campaign to another. However, no record of antenna height measurements were kept in the earlier campaigns, which necessitated that we took special care in processing the data (see Section 3.2).

\section{Data Analysis}

\subsection{IGS data analysis}

Before analyzing campaign GPS data collected near Syowa Station, we analyzed data from the IGS stations in order to reevaluate the Antarctic plate motion. As mentioned, there are nine IGS sites on the Antarctic plate (Fig. 1). Due to most of the Antarctic continent being covered with a thick ice sheet, bedrock outcrops can only be found at coastal areas and at a small number of mountain outcrops, where these IGS sites are located. We analyzed data from all nine IGS sites to obtain daily coordinate solutions for 6 years from 1998 to 2003 .

Several researchers have already discussed GPS measurements around Antarctica. Bouin and Vigny (2000) analyzed GPS data from six IGS sites for four years (19951998); however, their analysis did not include data from the SYOG site at Syowa Station. Yamada et al. (1998) analyzed seven sites, including the SYOG site, for 1 year (July 1996June 1997). Data from seven continuously occupied IGS sites and two original quasi-continuous sites near MCM4 were analyzed by Raymond et al. (2004) from 1996 to 2001; however, they somehow omitted to provide an error estimate for horizontal velocities. In contrast, Dietrich et al. (2004) discussed the crustal deformation of Antarctica based on GPS data obtained from nine IGS sites and 26 campaign sites between 1995 and 1998. As their discussion was focused on the deformation of the Antarctic Peninsula, and they did not give velocity estimate errors. Prawirodirdjo and Bock (2004) analyzed available IGS data between 1991 and 2003 and estimated global plate motion, including that of the Antarctic plate. Data obtained from seven IGS sites located on the Antarctic plate were used in their analysis, but a detailed description of Antarctic plate motion was beyond the scope of their investigation.

Our analysis is based on data collected from nine IGS sites for 6 years (January 1998 to December 2003). Because the SYOG site experienced a problem with the receiver clock until 1998, we limited our analysis to data collected 
Table 1. Summary of campaign GPS data.

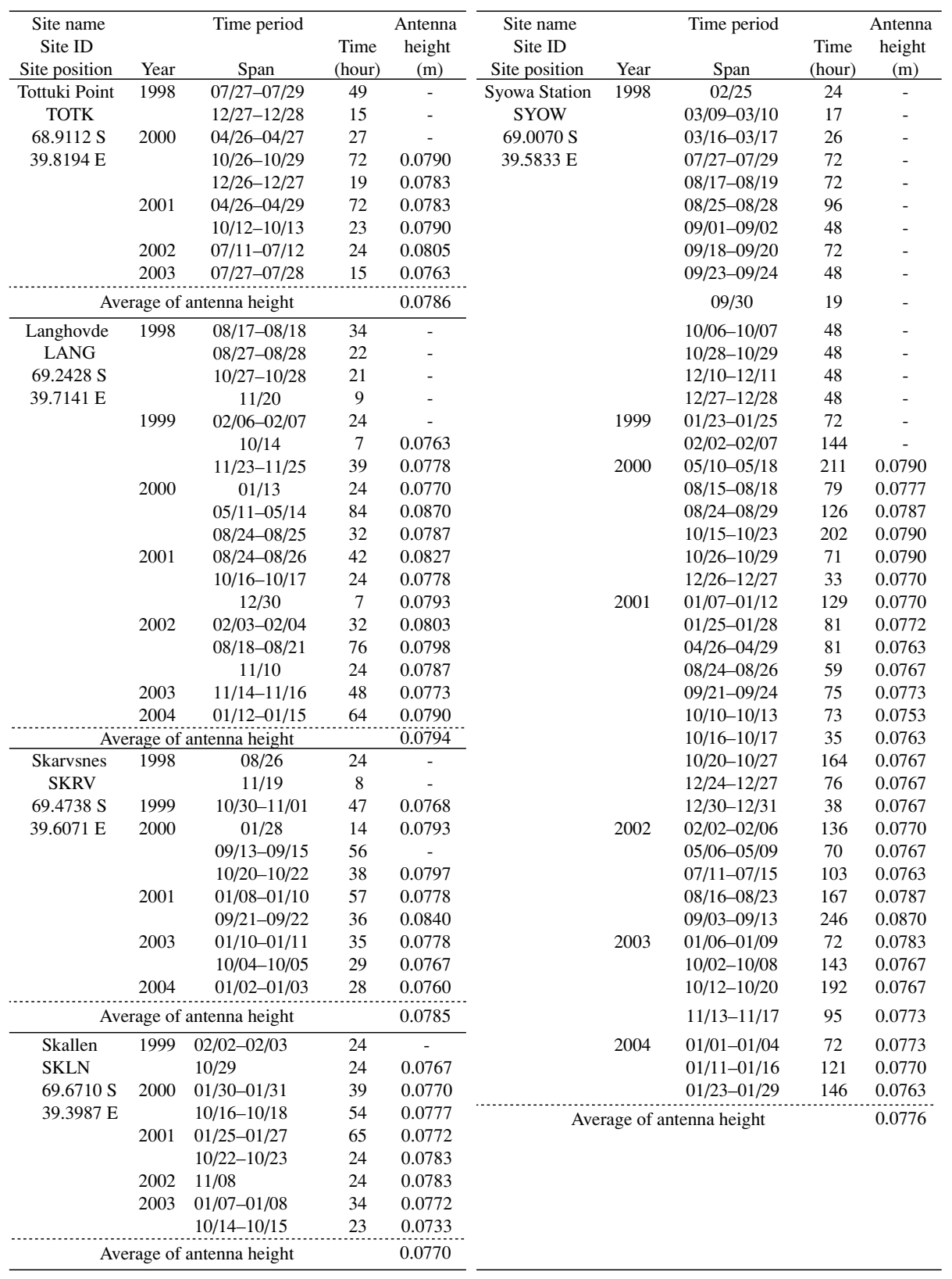

after that time. The campaign GPS observations around Syowa Station cover almost the same time span.

We used the precise point positioning (PPP) method (Zumberge et al., 1997) with GIPSY/OASIS II software (Jet Propulsion Laboratory (JPL), Pasedena, Calif.). Daily coordinate solutions were estimated by referring to the ITRF 2000 coordinate system (Altamimi et al., 2002) using precise orbits and clock correction information provided by JPL. We applied the ocean tide model and atmospheric correction in this analysis. Figure 2 is a time series plot of daily coordinate solutions for all sites and shows quite clearly that there is neither a significant step nor a trend change at any site. We computed a site velocity for each IGS site by least squares method to each coordinate time series. The resultant site velocities are summarized in Table 2 and Fig. 3.

\subsection{Campaign GPS data analysis}

Our analysis of the campaign-mode GPS data obtained around Syowa Station was aimed at obtaining a picture of local crustal deformation. For this analysis, we conducted a baseline mode analysis using the Bernese GPS software version 4.2 (Hugentobler et al., 2001). Relative positioning with the IGS precise orbit generally yields an improved precision compared with the PPP method, and this fact was our motivation to apply a different analysis technique to the campaign data (see Zumberge et al., 1997). Because the PPP solution at SYOG in Syowa Station was consistent with that of ITRF 2000 results (Table 3), we used SYOG as the reference site, whose coordinates and velocity are strongly constrained with the ITRF 2000 solution in our analysis. Thus, we calculated daily coordinates of campaign sites in the ITRF 2000 reference frame.

Coordinate time series of each campaign site are shown 

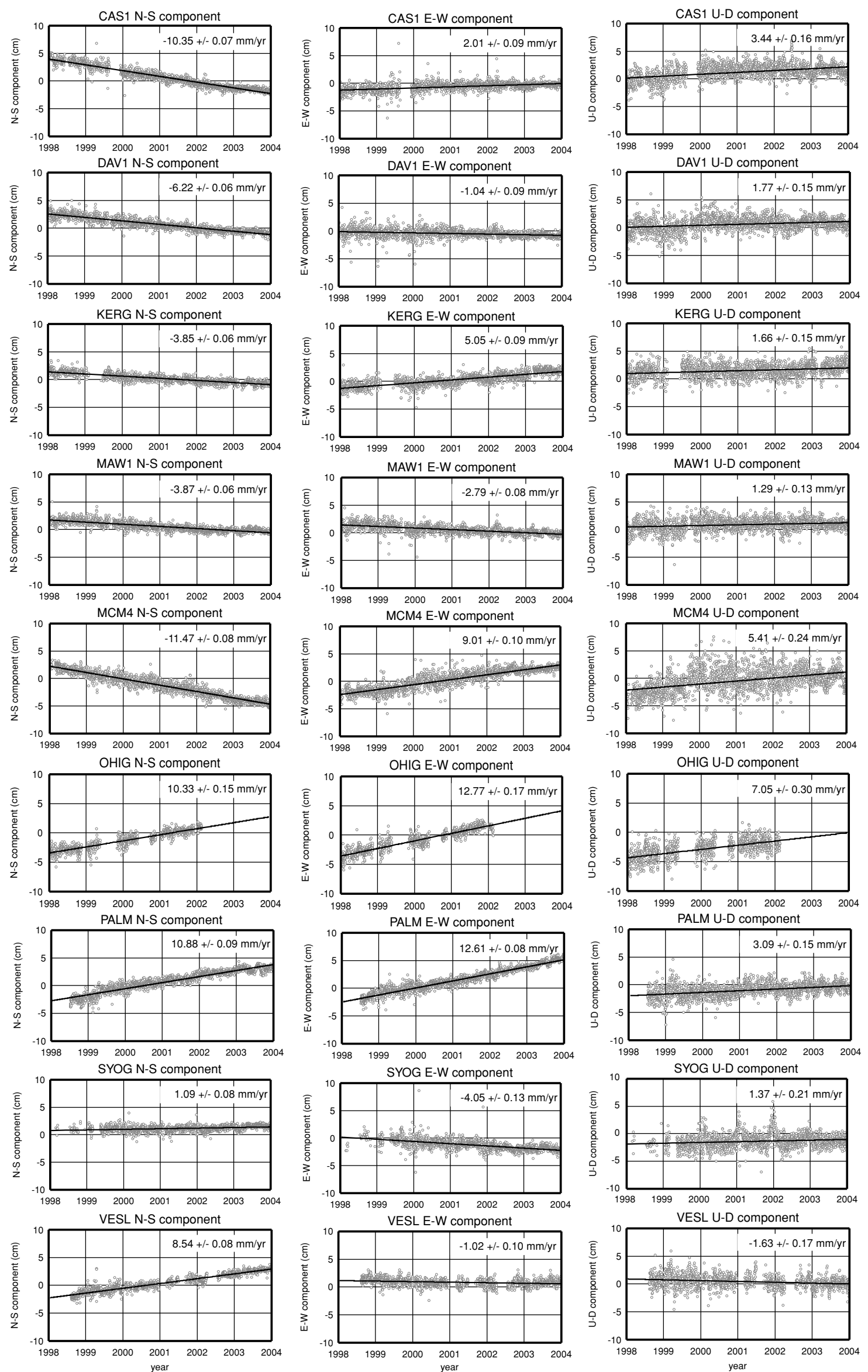

Fig. 2. Coordinate time series of north-south, east-west, and up-down components at IGS sites. Northward, eastward, and upward velocities are plotted positive. 
Table 2. IGS sites velocities.

\begin{tabular}{|c|c|c|c|c|}
\hline \multirow{2}{*}{$\begin{array}{c}\text { Station ID Station Name } \\
\text { Position }\end{array}$} & & \multicolumn{3}{|c|}{ Velocity } \\
\hline & & $\mathrm{N}-\mathrm{S}(\mathrm{mm} / \mathrm{yr})$ & E-W (mm/yr) & $\mathrm{U}-\mathrm{D}(\mathrm{mm} / \mathrm{yr})$ \\
\hline $\begin{array}{ll}\text { CAS1 } & \text { Casey }\end{array}$ & this study & $-10.4 \pm 0.1$ & $2.0 \pm 0.1$ & $3.4 \pm 0.2$ \\
\hline \multirow{6}{*}{$66.2834 \mathrm{~S} 110.5197 \mathrm{E}$} & NNR-NUVEL-1A & -8.8 & 1.2 & - \\
\hline & ITRF 2000 & $-9.6 \pm 0.7$ & $2.6 \pm 0.2$ & $3.8 \pm 3.0$ \\
\hline & REVEL & $-11.6 \pm 0.7$ & $3.7 \pm 0.6$ & $6.4 \pm 1.5$ \\
\hline & Dietrich et al. (2004, Solution B) & -12.4 & 5.4 & - \\
\hline & Prawirodirdjo and Bock (2004) & $-9.9 \pm 0.3$ & $2.0 \pm 0.3$ & $4.6 \pm 0.9$ \\
\hline & Raymond et al. (2004) & -11.2 & 2.7 & $4.6 \pm 1.1$ \\
\hline $\begin{array}{ll}\text { DAV1 } & \text { Davis }\end{array}$ & this study & $-6.2 \pm 0.1$ & $-1.0 \pm 0.1$ & $1.8 \pm 0.1$ \\
\hline \multirow[t]{6}{*}{$68.5773 \mathrm{~S} 77.9726 \mathrm{E}$} & NNR-NUVEL-1A & -2.9 & -2.3 & - \\
\hline & ITRF 2000 & $-4.8 \pm 0.2$ & $-1.5 \pm 0.3$ & $4.2 \pm 0.7$ \\
\hline & REVEL & $-6.6 \pm 0.7$ & $-2.1 \pm 0.7$ & $4.0 \pm 1.5$ \\
\hline & Dietrich et al. (2004, Solution B) & -10.3 & -0.9 & - \\
\hline & Prawirodirdjo and Bock (2004) & $-5.1 \pm 0.3$ & $-1.9 \pm 0.3$ & $3.2 \pm 0.6$ \\
\hline & Raymond et al. (2004) & -5.6 & -1.7 & $1.7 \pm 1.1$ \\
\hline $\begin{array}{ll}\text { KERG } & \text { Kerguelen }\end{array}$ & this study & $-3.8 \pm 0.1$ & $5.0 \pm 0.1$ & $1.7 \pm 0.2$ \\
\hline \multirow[t]{6}{*}{$49.3515 \mathrm{~S} 70.2555 \mathrm{E}$} & NNR-NUVEL-1A & -1.3 & 6.3 & - \\
\hline & ITRF 2000 & $-3.1 \pm 0.1$ & $5.9 \pm 0.2$ & $5.0 \pm 1.2$ \\
\hline & REVEL & $-5.3 \pm 0.7$ & $5.2 \pm 0.8$ & $6.5 \pm 1.5$ \\
\hline & Dietrich et al. (2004, Solution B) & -3.9 & 6.4 & - \\
\hline & Prawirodirdjo and Bock (2004) & $-3.8 \pm 0.3$ & $5.9 \pm 0.4$ & $4.8 \pm 0.8$ \\
\hline & Raymond et al. (2004) & - & - & - \\
\hline $\begin{array}{ll}\text { MAW1 } & \text { Mawson }\end{array}$ & this study & $-3.9 \pm 0.1$ & $-2.8 \pm 0.1$ & $1.3 \pm 0.1$ \\
\hline \multirow[t]{6}{*}{67.6048 S $62.8707 \mathrm{E}$} & NNR-NUVEL-1A & 0.3 & -2.1 & - \\
\hline & ITRF 2000 & $-2.7 \pm 0.3$ & $-2.3 \pm 0.2$ & $2.8 \pm 3.1$ \\
\hline & REVEL & $-3.6 \pm 0.7$ & $-3.5 \pm 0.7$ & $3.9 \pm 1.3$ \\
\hline & Dietrich et al. $(2004$, Solution B) & -7.8 & -2.8 & - \\
\hline & Prawirodirdjo and Bock (2004) & $-3.3 \pm 0.5$ & $-1.8 \pm 0.6$ & $1.4 \pm 1.1$ \\
\hline & Raymond et al. (2004) & -4.7 & -2.8 & $0.4 \pm 2.3$ \\
\hline $\begin{array}{ll}\text { MCM4 } & \text { McMurdo }\end{array}$ & this study & $-11.5 \pm 0.1$ & $9.0 \pm 0.1$ & $5.4 \pm 0.2$ \\
\hline \multirow{6}{*}{$77.8383 \mathrm{~S} 166.6693 \mathrm{E}$} & NNR-NUVEL-1A & -11.8 & 7.6 & - \\
\hline & ITRF 2000 & $-12.0 \pm 0.2$ & $9.7 \pm 0.3$ & $0.8 \pm 1.4$ \\
\hline & REVEL & $-12.2 \pm 0.6$ & $10.6 \pm 0.7$ & $4.6 \pm 1.9$ \\
\hline & Dietrich et al. $(2004, \text { Solution B })^{1}$ & 11.8 & 15.1 & - \\
\hline & Prawirodirdjo and Bock (2004) & $-11.6 \pm 0.3$ & $8.7 \pm 0.3$ & $2.2 \pm 1.1$ \\
\hline & Raymond et al. (2004) & -11.9 & 10.0 & $-1.1 \pm 1.1$ \\
\hline $\begin{array}{ll}\text { OHIG } & \text { O'Higgins }\end{array}$ & this study & $10.3 \pm 0.1$ & $12.8 \pm 0.2$ & $7.0 \pm 0.3$ \\
\hline \multirow[t]{6}{*}{$63.3211 \mathrm{~S} 57.9013 \mathrm{~W}$} & NNR-NUVEL-1A & 10.3 & 16.4 & - \\
\hline & ITRF 2000 & $10.2 \pm 0.2$ & $14.4 \pm 0.1$ & $9.5 \pm 1.2$ \\
\hline & REVEL & $10.1 \pm 0.9$ & $14.7 \pm 0.8$ & $8.7 \pm 1.8$ \\
\hline & Dietrich et al. $(2004$, Solution B) & 11.8 & 10.3 & - \\
\hline & Prawirodirdjo and Bock (2004) & - & - & - \\
\hline & Raymond et al. (2004) & 11.3 & 13.7 & $6.5 \pm 1.1$ \\
\hline $\begin{array}{ll}\text { PALM } & \text { Palmer }\end{array}$ & this study & $10.9 \pm 0.1$ & $12.6 \pm 0.1$ & $3.1 \pm 0.2$ \\
\hline \multirow{6}{*}{$64.7751 \mathrm{~S} 64.0511 \mathrm{~W}$} & NNR-NUVEL-1A & 9.5 & 16.9 & - \\
\hline & ITRF 2000 & $12.0 \pm 0.3$ & $12.6 \pm 0.2$ & $2.5 \pm 2.8$ \\
\hline & REVEL & $14.1 \pm 1.9$ & $11.7 \pm 1.5$ & $3.3 \pm 3.4$ \\
\hline & Dietrich et al. (2004, Solution B) & 14.4 & 11.7 & - \\
\hline & Prawirodirdjo and Bock (2004) & - & - & - \\
\hline & Raymond et al. (2004) & - & - & - \\
\hline $\begin{array}{ll}\text { SYOG } & \text { Syowa }\end{array}$ & this study & $1.1 \pm 0.1$ & $-4.1 \pm 0.1$ & $1.4 \pm 0.2$ \\
\hline \multirow[t]{6}{*}{69.0070 S $39.5837 \mathrm{E}$} & NNR-NUVEL-1A & 5.0 & -1.8 & - \\
\hline & ITRF 2000 & $1.3 \pm 0.4$ & $-3.6 \pm 0.1$ & $2.1 \pm 2.1$ \\
\hline & REVEL & $0.3 \pm 1.0$ & $-4.4 \pm 1.2$ & $5.8 \pm 2.2$ \\
\hline & Dietrich et al. (2004, Solution B) & -3.4 & -5.8 & - \\
\hline & Prawirodirdjo and Bock (2004) & $2.5 \pm 0.7$ & $-3.7 \pm 0.9$ & $3.5 \pm 1.7$ \\
\hline & Raymond et al. (2004) & 0.2 & -5.1 & $2.1 \pm 2.3$ \\
\hline & this study & $8.5 \pm 0.1$ & $-1.0 \pm 0.1$ & $-1.6 \pm 0.2$ \\
\hline \multirow[t]{6}{*}{$71.6738 \mathrm{~S} 2.8417 \mathrm{~W}$} & NNR-NUVEL-1A & 11.1 & 3.0 & - \\
\hline & ITRF 2000 & $11.1 \pm 0.6$ & $2.3 \pm 0.9$ & $-1.0 \pm 1.3$ \\
\hline & REVEL & $8.2 \pm 1.8$ & $-4.7 \pm 1.4$ & $1.1 \pm 3.6$ \\
\hline & Dietrich et al. (2004, Solution B) & 6.6 & -4.7 & - \\
\hline & Prawirodirdjo and Bock (2004) & $8.6 \pm 0.7$ & $-0.1 \pm 0.7$ & $-1.5 \pm 1.2$ \\
\hline & Raymond et al. (2004) & 8.2 & -2.9 & $-1.9 \pm 2.0$ \\
\hline
\end{tabular}

${ }^{1}$ They used MCMU data. This site is removed in 1995.

in Fig. 4. Each dot denotes a single campaign, showing thereby an average of daily coordinates within each campaign. Error bar is estimated as a root-mean-square error and represents daily repeatability. For campaigns with single-day observations, the error bars denote the nominal standard deviation of GPS analysis.

As mentioned in the preceding section, there are no records of antenna height in earlier campaigns (see Table 1). For those campaigns without antenna height measurement, we first assumed zero antenna height in the baseline analysis. Since the same equipment has been used throughout all the campaigns and the measured antenna heights in the later campaigns did have similar values with a difference of only a few millimeters, we made a correction on the vertical component of our campaign coordinate solution by adding an antenna height based on the average of all measured records for the same site. These corrected values are denoted as black dots in Fig. 4. It is clear from Fig. 4 that 


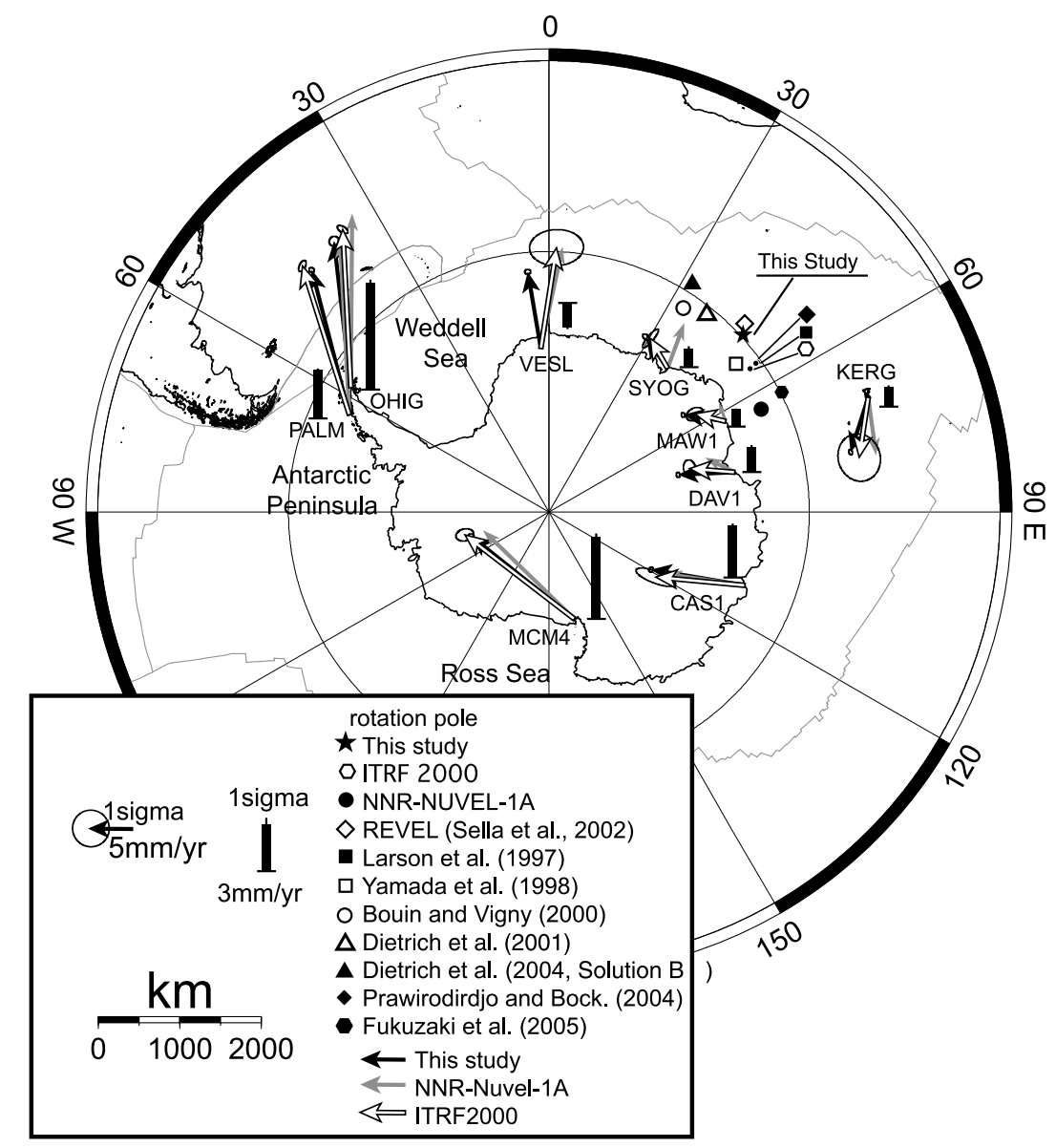

Fig. 3. Comparison of observed velocities, ITRF 2000 results, and NNR-NUVEL-1A predictions. Also shown are rotation pole positions of the Antarctic plate obtained by previous studies.

observations made with and without antenna height measurements are aligned along similar trend lines, implying a successful correction of antenna heights. On the other hand, we did not make a correction for the horizontal components since the antenna height correction affects only the vertical component of site coordinates.

We found large scatters in the vertical components at the SYOW site in the summers (beginning of the year) of 1999 , 2001, and 2002. In addition, Fig. 2 shows that there are systematic upward shifts by about $5 \mathrm{~cm}$ in the vertical component of SYOG station almost every summer. Since this phenomenon is only found around Syowa Station, there may be an error source during the summer season that biases a vertical component of GPS measurement. Unfortunately, we have been unable to isolate the cause of this bias to date.

We estimated site velocities by fitting a linear trend to each coordinate time series by the least squares method. The fitted linear trends are shown in Fig. 4 as straight lines. In this analysis, we used all of the data, regardless of the noted antenna height corrections, and were able to confirm that the inclusion - or not - of the antenna height measurements did not significantly affect the results.

\section{Discussion}

\subsection{Antarctic plate motion}

In Fig. 3 we compare the velocity vectors that we computed using the data set from the IGS sites with those pre-
Table 3. Rotation pole position of the Antarctic plate.

\begin{tabular}{|c|c|c|c|}
\hline \multirow{2}{*}{ Model } & \multicolumn{2}{|c|}{ Pole position } & \multirow{2}{*}{$\begin{array}{l}\text { Angular velocity } \\
\text { (deg/Ma) }\end{array}$} \\
\hline & Latitude (deg) N & Longitude (deg) W & \\
\hline This study & $59.7 \pm 0.1$ & $132.3 \pm 0.1$ & $0.21 \pm 0.01$ \\
\hline ITRF 2000 & $61.8 \pm 2.1$ & $125.6 \pm 3.7$ & $0.23 \pm 0.02$ \\
\hline NNR-NUVEL-1A & 63.0 & 115.9 & 0.24 \\
\hline REVEL & 58.5 & 134.0 & 0.23 \\
\hline Larson et al. (1997) & 60.5 & 125.7 & 0.24 \\
\hline Yamada et al. (1998) & 62.7 & 128.4 & 0.22 \\
\hline Bouin and Vigny (2000) & 62.0 & 146.7 & 0.26 \\
\hline Dietrich et al. (2001) & 60.8 & 141.1 & 0.26 \\
\hline Dietrich et al. $(2004$, solution B) & 58.7 & 147.9 & 0.21 \\
\hline Prawirodirdjo and Bock (2004) & 60.7 & 125.7 & 0.22 \\
\hline Fukuzaki et al. (2005) & 59.7 & 117.4 & 0.19 \\
\hline
\end{tabular}

dicted by a global plate motion model, NNR-NUVEL-1A (Argus and Gordon, 1991; DeMets et al., 1994), and the ITRF 2000 solution (Boucher et al., 2004). Our solution is mostly consistent with the ITRF 2000 solution within 1-sigma except for VESL. On the other hand, there are systematic differences between our solution and that of the NNR-NUVEL-1A model, with the differences being significant at SYOG, MAW1, DAV1, KERG, and VESL. Table 2 presents a comparison of our velocity estimates with those of previous studies; attention should be paid to the fact that these latter studies are based on different data sets and assumptions. First, NNR-NUVEL-1A is based on geologic as well as geodetic data, and ITRF 2000 was obtained as 

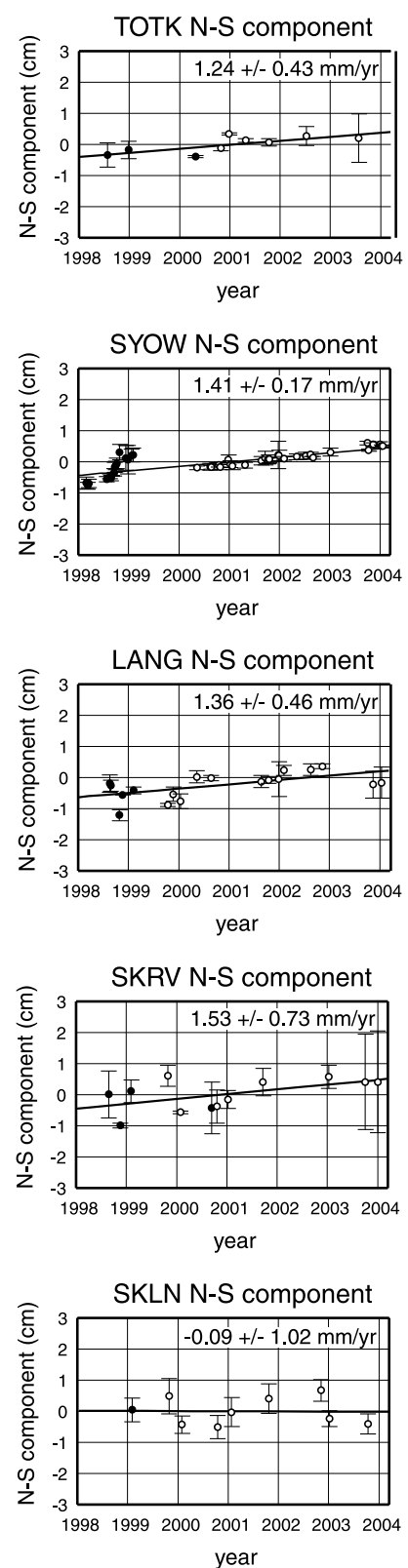

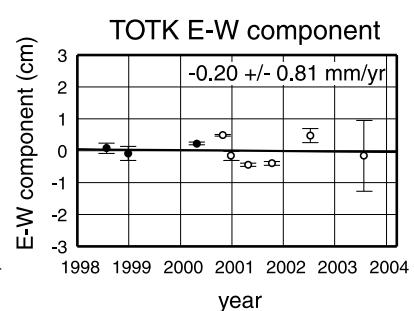

SYOW E-W component

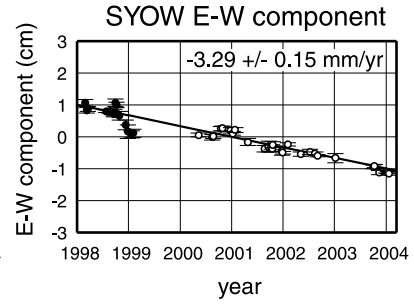

year
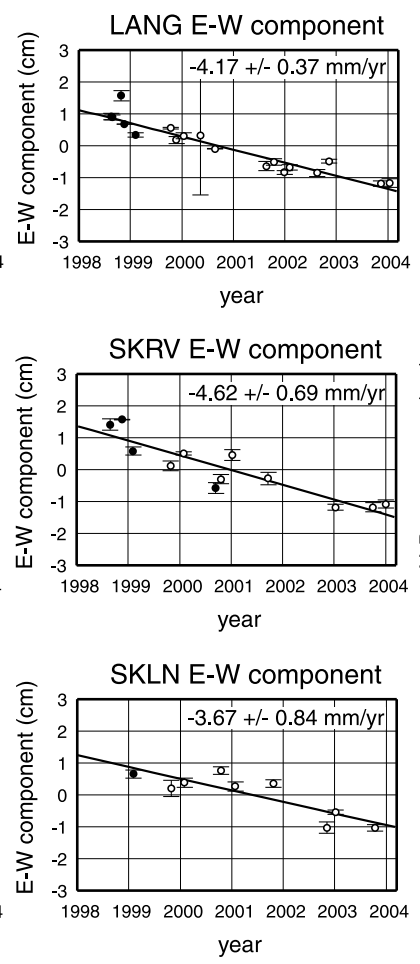

TOTK U-D component

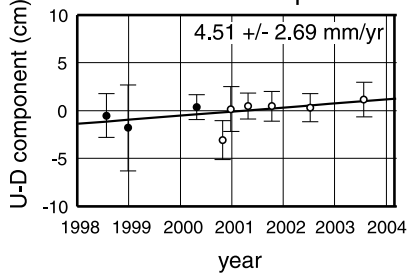

SYOW U-D component

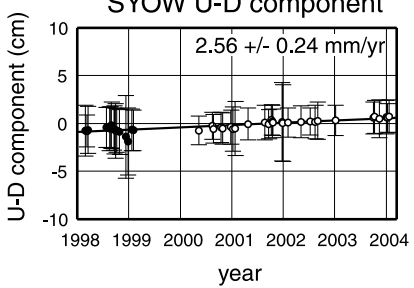

LANG U-D component
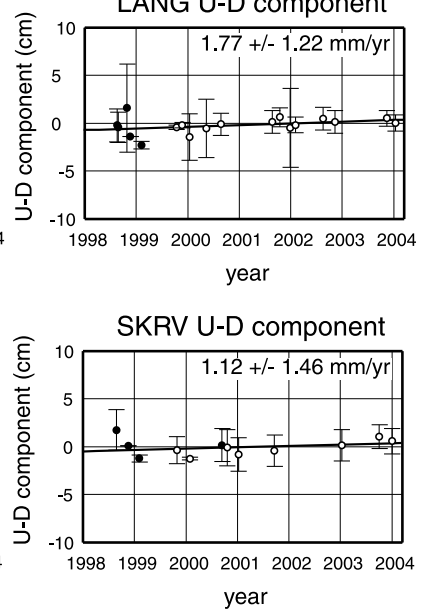

SKLN U-D component

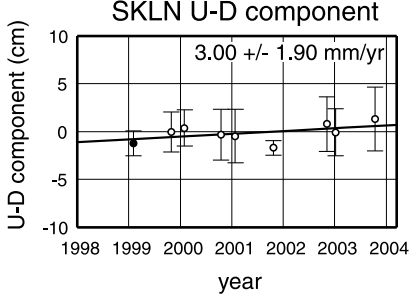

Fig. 4. Coordinate time series of campaign GPS sites. One dot represents a single campaign result. Dots in black indicate the campaigns with antenna height corrections because of the absence of height measurement records.

a weighted average of different space-geodetic techniques; the remaining results are based purely on GPS data. Secondly, with respect to the reference frame, REVEL (Sella et al., 2002) refers to ITRF 97, while the other GPS results were based on ITRF 2000. In addition, there are differences in error models: REVEL and Prawirodirdjo and Bock (2004) incorporated white as well as colored noise components in their error estimates, while other studies assumed a white noise only, resulting in smaller velocity estimation errors. A comparison of the velocity error of the present study with that Prawirodirdjo and Bock (2004) reveals that our velocity errors would become three- to fivefold larger if we had incorporated colored noise components.

Of the six sets of velocity data presented in Table 2, our velocity results are closest to those of Prawirodirdjo and Bock (2004) and ITRF 2000, possibly indicating that different velocity solutions would converge towards one an- other as the analysis period is extended. On the other hand, the vertical velocity components show large differences $(>4$ $\mathrm{mm} /$ year) at KERG, MCM4, and SYOG. However, these results should be interpreted with care because there are some disadvantageous conditions specific to polar regions. For example, the constellation of GPS satellites is worse in Antarctica. In addition, since the number of observation sites for the terrestrial reference frame (TRF) definition is smaller in Antarctica, this may cause a systematic bias in the surrounding areas. While this topic requires-and deserves - an in-depth discussion, it is beyond the scope of our analysis. This problem will have to be left for future researchers who have made enough observations to resolve it.

The rotation pole position and the angular velocity of the Antarctic plate were estimated as $59.95 \pm 0.32^{\circ} \mathrm{N}$, $130.86 \pm 0.42^{\circ} \mathrm{W}$ and $0.21 \pm 0.002^{\circ} / \mathrm{Ma}$, respectively, based 


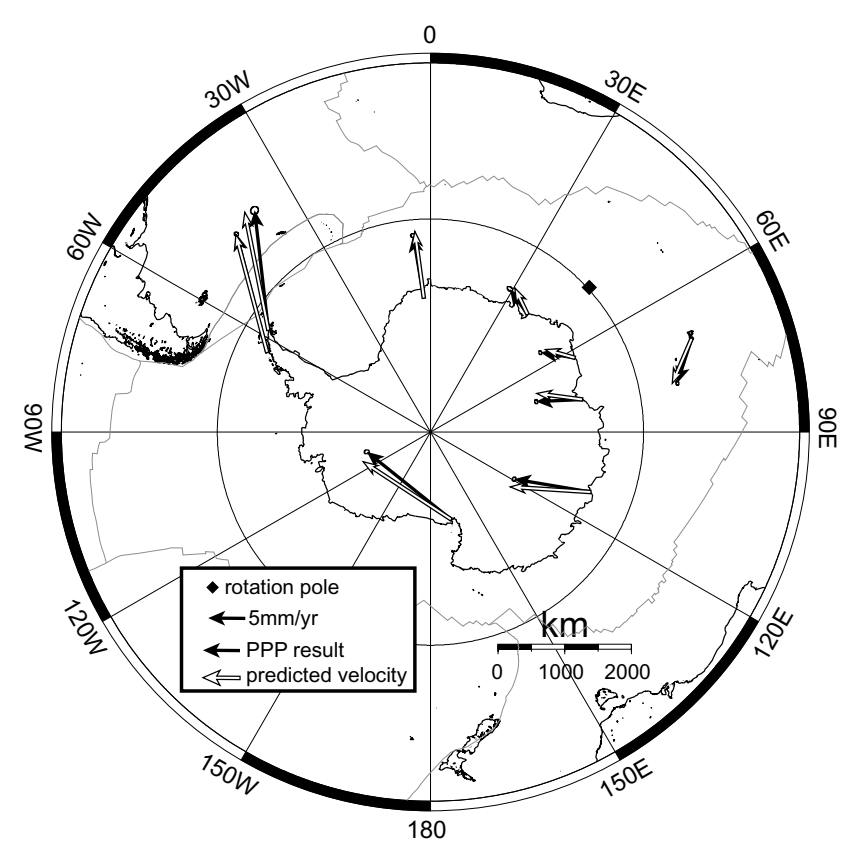

Fig. 5. Observed horizontal velocities and predictions from the rigid plate motion model.

on our site velocities. A comparison of our estimate with those of ten earlier studies is shown in Fig. 3 and Table 3. All rotation poles are located close to one another between latitudes $58.5^{\circ} \mathrm{N}$ and $63.0^{\circ} \mathrm{N}$ and between longitudes $115.9^{\circ} \mathrm{W}$ and $147.9^{\circ} \mathrm{W}$. We were able to group these 11 pole positions into three. The first group is associated with the solutions of Bouin and Vigny (2000), and Dietrich et al. $(2001,2004)$ and is located at a lower longitude than our result. The second group is the higher longitude position of NNR-NUVEL-1A and Fukuzaki et al. (2005). The final group includes our results and contains six estimated poles. As most of the results in the last group are estimated from stable, continuous observation, we propose that the real rotation pole can be located in this area. On the other hand, the former two groups contain some differences from our estimate technique, such as the number of IGS sites used or the VLBI epoch referred.

Figure 5 shows a comparison between our PPP solutions and the predicted velocities based on our rotation pole. Two velocity vectors are highly consistent each other, with discrepancies of less than $1 \mathrm{~mm} / \mathrm{year}$ at all the sites. This comparison clearly demonstrates a high rigidity of the Antarctic plate. Since the Antarctic plate is $6,000-10,000 \mathrm{~km}$ wide in diameter, discrepancies of less than $1 \mathrm{~mm} / \mathrm{year}$ from the rigid plate motion indicate that the average intercontinental strain rate of the Antarctic plate is on the order of $10^{-9}$ $10^{-10}$ /year. Therefore, we can say that the Antarctic plate moves as a rigid plate with almost no inner deformation.

Site velocities around Syowa Station based on the campaign GPS data are shown in Fig. 6 and presented in Table 4. The horizontal components at SYOW, LANG, and SKRV agree with each other within 1 standard deviation. Furthermore, these velocities agree with the SYOG velocity presented in Table 2 . Thus, we are able to confirm that the SYOG motion properly represents crustal movement

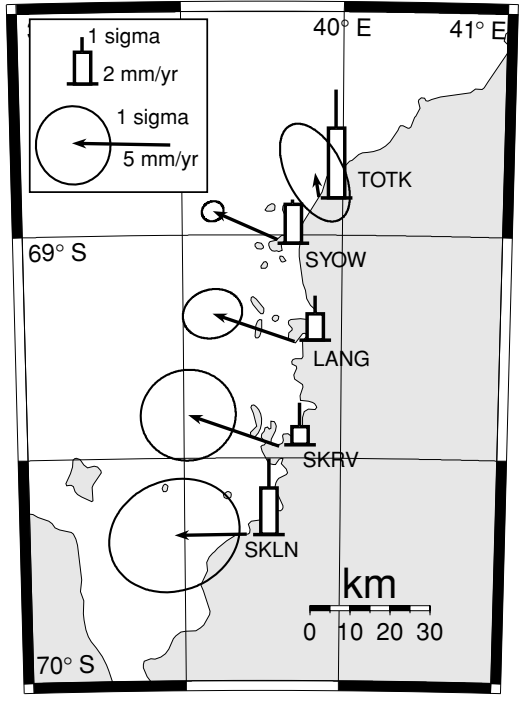

Fig. 6. Velocities obtained by campaign GPS measurements around Syowa Station.

Table 4. Velocities of campaign GPS sites.

\begin{tabular}{ccccccc}
\hline Station ID & N-S $(\mathrm{mm} / \mathrm{yr})$ & \multicolumn{2}{c}{ E-W $(\mathrm{mm} / \mathrm{yr})$} & \multicolumn{2}{c}{ U-D $(\mathrm{mm} / \mathrm{yr})$} \\
\hline TOTK & $1.24 \pm 0.43$ & $-0.20 \pm 0.81$ & $4.51 \pm 2.69$ \\
SYOW & $1.41 \pm 0.17$ & -3.29 & \pm 0.15 & $2.56 \pm 0.24$ \\
LANG & $1.36 \pm 0.46$ & $-4.17 \pm 0.37$ & $1.77 \pm 1.12$ \\
SKRV & $1.53 \pm 0.73$ & $-4.62 \pm 0.69$ & $1.12 \pm 1.46$ \\
SKLN & $-0.09 \pm 1.02$ & $-3.67 \pm 0.84$ & $3.00 \pm 1.90$ \\
\hline
\end{tabular}

Table 5. Site velocities of SYOG and OHIG.

\begin{tabular}{lccc}
\hline SYOG & N-S component & E-W component & U-D component \\
\hline This Study & $1.1 \pm 0.1$ & $-4.1 \pm 0.1$ & $1.4 \pm 0.2$ \\
Fukuzaki et al. (2005) & $4.0 \pm 0.7$ & $-2.5 \pm 0.6$ & $4.6 \pm 2.2$ \\
ITRF 2000 & $1.3 \pm 0.4$ & $-3.7 \pm 0.1$ & $2.1 \pm 2.1$ \\
\hline \hline OHIG & N-S component & E-W component & U-D component \\
\hline This Study & $10.3 \pm 0.1$ & $12.8 \pm 0.2$ & $7.0 \pm 0.3$ \\
Fukuzaki et al. (2005) & $9.0 \pm 0.2$ & $12.7 \pm 0.2$ & $4.5 \pm 0.7$ \\
ITRF 2000 & $10.2 \pm 0.2$ & $14.4 \pm 0.1$ & $9.5 \pm 1.2$ \\
\hline
\end{tabular}

around the Soya Coast, which is in accordance with the overall plate motion of Antarctica. Velocities of SKLN and TOTK are different from those of other three sites and, in addition, both sites have large uncertainties. Consequently, we are unable to draw any conclusions on the movements of these two sites. It will be necessary to carry out more campaign observations to improve velocity estimations at these sites.

\subsection{Comparison with previous GIA models}

With respect to the vertical component, almost all of the sites show uplift. Coastal IGS sites around Enderby Land (SYOG, MAW1, and DAV1) consistently show a secular uplift of 1.4-1.8 mm/year (Fig. 3). Similarly, the uplift rates at campaign sites that agree with SYOG motions are roughly $1.1-2.5 \mathrm{~mm} /$ year (Table 4 ). On the other hand, the uplift rate is larger at CAS1 and MCM4. Since the horizontal motion of these sites indicates that the Antarctic continent behaves like a rigid block, it is reasonable to ascribe this uplift trend to postglacial rebound.

There are several studies that estimate current uplift velocities by using GIA theory and specific melting history of the ice sheet in question (see James and Ivins, 1998; Nakada 
et al., 2000), and we compare our observations with those predicted by one of them (Nakada et al., 2000). It is worthwhile pointing out that horizontal velocities predicted from a majority of the models are less than $1 \mathrm{~mm} /$ year and, therefore, these can be interpreted as being within the uncertainty level of the observation. For this reason, we discuss only vertical components as they may contain a significant rebound signature.

We need to examine three features concurrently based on a comparison of our analysis and model predictions. First, some models, such as ICE-3G (Tushingham and Peltier, 1991) and D91 (Denton et al., 1991; James and Ivins, 1998) predicted a large (over $4 \mathrm{~mm} /$ year) uplift rate around observation sites SYOG, MAW1, and DAV1. However, the observed uplift rate was as small as $1-2 \mathrm{~mm} /$ year in these areas. Second, uplift rates predicted from several models disagree with one another around the Ross and Weddell embayments. Nakada et al. (2000) assumed a comparatively smaller ice sheet melting in the Ross Sea and subsequently predicted uplift velocity of approximately 1 $\mathrm{mm} /$ year around the MCM4 site. On the other hand, other models, such as ANT3 (Nakada and Lambeck, 1988), ANT4 (Nakada and Lambeck, 1989), ICE-3G (Tushingham and Peltier, 1991), HB (Huybrechts, 1990), and D91 (Denton et al., 1991; James and Ivins, 1998) assumed a larger ice sheet melting in the Ross Sea and in the Weddell Sea regions, subsequently predicting uplift rates of 4-6 mm/year. The observed uplift rate at MCM4 favors the latter models. The last point is crustal movements around the Antarctic Peninsula. OHIG at the front edge of the Peninsula appears to be uplifting at a rate of $7 \mathrm{~mm} /$ year, while at PALM, on the western coast, the uplifting rate is $3 \mathrm{~mm} /$ year. As for the uplift movements of the Antarctic Peninsula itself, some studies (e.g. Sella et al., 2002) have found results similar to ours. However, most of the GIA models predict the largest uplift (6-14 mm/year) at the southeastward route of the Peninsula and a smaller uplift toward its northwestward tip. This discrepancy may be interpreted to be the result of a smallscale feature of the ice sheet or its recent changes, as has been pointed out by Ivins et al. (2000).

Based on these comparisons, we conclude that none of the proposed models can successfully reproduce the present crustal movement of Antarctica, although we do find that ICE-3G and D91 are better than other models. On the whole, these two models show a good consistency with the GPS results, although they do predict a larger uplift around Enderby Land (SYOG, MAW1, and DAV1). For more precise comparison, it will most likely be necessary to consider a more refined treatment of ice sheet evolution on a smaller scale and the heterogeneous structure beneath Antarctica, such as lithospheric thickness and the asthenospheric viscosity.

\subsection{Comparison with VLBI results at Syowa Station}

VLBI measurements have been carried out at Syowa Station since 1999 (Fukuzaki et al., 2005). The VLBI monument at Syowa Station was built approximately $120 \mathrm{~m}$ from the IGS site SYOG. Fukuzaki et al. (2005) analyzed baseline lengths of Syowa from Hobart (HOB2, Australia), Hart RAO (HRAO, South Africa), and O'Higgins (OHIG, Antarctic Peninsula) using CALC/SOLVE software devel- oped by the NASA Goddard Space Flight Center (GSFC). They estimated the N-S, E-W, and U-D components of the VLBI displacement rates at Syowa Station to be $4.0 \pm 0.7$, $-2.5 \pm 0.6$, and $4.6 \pm 2.2 \mathrm{~mm} /$ year, respectively, in the ITRF 2000 coordinate system. Therefore, the velocity as determined by VLBI and GPS (SYOG) disagree each other because our GPS results at SYOG were $1.1 \pm 0.1,-4.1 \pm 0.1$, and $1.4 \pm 0.2 \mathrm{~mm} /$ year, respectively. In brief, the VLBI velocity shows a shift towards the northeast by approximately $3.3 \mathrm{~mm} /$ year relative to our GPS results. With respect to the vertical component, the VLBI uplift rate is larger than its GPS counterpart by about $3 \mathrm{~mm} /$ year.

Fukuzaki et al. (2005) also estimated a rotation pole position as well as an angular velocity of the Antarctic plate from VLBI results at Syowa Station and O'Higgins as $59.7^{\circ} \mathrm{N}, 117.4^{\circ} \mathrm{W}$ and $0.19^{\circ} / \mathrm{Ma}$, respectively. This result is again significantly different from our result but it is close to the rotation pole of NNR-NUVEL-1A (Table 3, Fig. 3).

In their calculations, Fukuzaki et al. (2005) assumed the ITRF 2000 velocity at HOB2 and HRAO and then derived velocities at SYOG and OHIG by using their VLBI baseline length change rates. Table 5 presents a comparison of the site velocities of SYOG and OHIG from our study with those from Fukuzaki et al. (2005) and the ITRF2000 solution. The VLBI velocity at OHIG by Fukuzaki et al. (2005) actually matches the ITRF 2000 solution, which is consistent with the result from the present study except for the vertical component. The significant discrepancy in horizontal components only exists in Syowa Station, which indicates that either the VLBI/ GPS solution at Syowa Station is in error or that it is somehow biased by geophysical or, perhaps, non-geophysical processes.

As we have discussed, the GPS estimate of velocity at SYOG is consistent with the velocities at other GPS sites on the rigid Antarctic plate. In addition, the campaign GPS solutions around Syowa Station have demonstrated that the SYOG motion represents regional crustal movement, free from a local deformation bias. Such evidence suggests that the VLBI solution at Syowa Station might be biased. Although we cannot identify the cause of this bias, it is essential to perform coordinated local network observations that include both the VLBI and the GPS instruments at Syowa Station. Since a relative movement over $3 \mathrm{~mm} / \mathrm{year}$ is expected between the two sites, such a motion can be detected within a few years rather easily.

\section{Conclusion}

We have analyzed two sets of GPS data in Antarctica. One is continuous observation data set from nine IGS sites collected between 1998 and 2003. Based on this analysis, we were able to estimate the motion of the whole Antarctic plate with the highest reliability to date. The horizontal component of the Antarctic plate motion can be explained as a rigid plate motion. The uplift velocities (except VESL) are interpreted to be an effect of the postglacial rebound, although the predictions from the current ice sheet models do not reproduce the observations. The second set of GPS data obtained by campaign-mode observations around Syowa Station provide independent evidence for the reliability of the result at SYOG. Sites located close to Syowa 
Station (SYOW, LANG, and SKRV) show approximately the same motion as SYOG IGS site. We can therefore conclude that the SYOG GPS data represent the crustal motion around Syowa Station. VLBI results differ from our GPS results. Detailed comparison between the VLBI and the GPS results indicate that the VLBI site at Syowa Station may be biased due to local deformation or some otheryet unknown-reason. It is necessary to conduct local tie observations between the VLBI and the GPS sites within Syowa Station for at least a few more years to resolve the present discrepancy.

Acknowledgments. We thank two reviewers, Dr. Erik R. Ivins and an anonymous reviewer, and our editor, Dr. Kosuke Heki, for very helpful comments and advice. We also would like to thank Shigeru Aoki, Sachiko Iwano, Koji Yoshii, and Yoshihiro Fukuzaki for having conducted the GPS campaign observations around Syowa Station as the JARE members.

\section{References}

Altamimi, Z, P. Sillard, and C. Boucher, ITRF 2000: A new release of the International Terrestrial Reference frame for each science applications, J. Geophys. Res., 107(B10), 2214, 2002.

Argus, D. F. and R. G. Gordon, No-Net-rotation model of current plate velocities incorporating plate motion model NUVEL-1, Geophys. Res. Lett., 18(11), 2039-2042, 1991.

Boucher, C., Z. Altamimi, P. Sillard, and M. Feissel-Vernier, The ITRF 2000, IERS Tech. Note, 31, 2004.

Bouin, N. M. and C. Vigny, New constraints on Antarctic plate motion and deformation from GPS data, J. Geophys. Res., 105, 28279-28293, 2000.

DeMets, C., R. G. Gordon, D. F. Argus, and S. Stein, Effect of recent revisions to the geomagnetic reversal timescale on estimates of current plate motions, Geophys. Res. Lett., 21(20), 2191-2194, 1994.

Denton, G. H., M. L. Prentice, and L. H. Burcle, Cainozoic history of Antarctic ice sheet, in Geology of America, edited by R. J. Tingey, pp. 365-433, Oxford University Press, New York, 1991.

Dietrich, R., R. Dach, G. Engelhardt, J. Ihde, W. Korth, H.-J. Kutterer, K. Lindner, M. Mayer, F. Menge, H. Miller, C. Müller, W. Niemeier, J. Perlt, M. Pohl, H. Salbach, H.-W. Schenke, T. Schöne, G. Seeber, A. Veit, and C. Völksen, ITRF coordinates and plate velocities from repeated GPS campaigns in Antarctica-an analysis based on different individual solutions, J. Geodyn., 74, 756-766, 2001.

Dietrich, R., A. Rülke, J. Ihde, K. Linder, H. Miller, W. Niemeier, H.-W. Schenke, and G. Seeber, Plate kinematics and deformation status of the Antarctic Peninsula based on GPS, Global Planet. Change, 42, 313 321, 2004.

Drewry, D. J., Antarctica: Glaciological and Geophysical Folio, Scotland Polar Research Institute, Cambridge, 1982.

Fukuzaki, Y., K. Shibuya, K. Doi, T. Ozawa, A. Nothnagel, T. Jike, S. Iwano, D. L. Jauncey, G. D. Nicolson, and P. M. McCulloch, Results of the VLBI experiments conducted with Syowa Station, Antarctica, $J$. Geodyn., 79, 379-388, 2005.

Hugentobler, U., S. Schaer, and P. Fridez (ed.), Documentation of the
Bernese GPS Software Version 4.2, 515 pp., 2001.

Hughes, T. J., G. H. Denton, B. G. Anderson, D. H. Schilling, J. L. Fastook, and C. S. Linge, The great ice sheets: a global view, in The Last Great Ice Sheets, edited by G. H. Denton and T. J. Hughes, pp. 263-317, Wiley, New York, 1981.

Huybrechts, A., A 3-D model for the Antarctic ice sheet: a sensitivity study on the glacial-interglacial contrast, Clim. Dyn., 5, 79-92, 1990.

Ivins, E. R., C. A. Raymond, and T. S. James, The influence of 5000 yearold and younger glacial mass variability on present-day crustal rebound in the Antarctic Peninsula, Earth Planets Space, 52, 1023-1029, 2000.

James, T. S. and E. R. Ivins, Predictions of Antarctic crustal motions driven by present-day ice sheet evolution and by isostatic memory of the Last Glacial Maximum, J. Geophys. Res., 103, 4993-5017, 1998.

Larson, K. M., J. T. Freymueller, and S. Philipsen, Global plate velocities from the Global Positioning System, J. Geophys. Res., 102, 9961-9981, 1997.

Nakada, M. and K. Lambeck, The melting history of the late Pleistocene Antarctic ice sheet, Nature, 333, 36-40, 1988.

Nakada, M. and K. Lambeck, Late Pleistocene and Holocene sea-level change in the Australian region and mantle rheology, Geophys. J., 96, 497-517, 1989.

Nakada, M., R. Kimura, J. Okuno, K. Moriwaki, H. Miura, and H. Maemoku, Late Pleistocene and Holocene melting history of the Antarctic ice sheet derived from sea-level variations, Mar. Geol., 167, 85-103, 2000.

Peltier, W. R., Ice age paleotopography, Science, 265, 195-201, 1994.

Prawirodirdjo, L. and Y. Bock, Instantaneous global plate motion model from 12 years of continuous GPS observations, J. Geophys. Res., 109 B08405, 2004.

Raymond, C. A., E. R. Ivins, M. B. Heflin, and T. S. James, Quasicontinuous global positioning system measurements of glacial isostatic deformation in the Northern Transantarctic Mountains, Global Planet. Change, 42, 295-303, 2004.

Sella, G. F., T. H. Dixon, and A. Mao, REVEL: A model for recent plate velocities from space geodesy, J. Geophys. Res., 107, 2081-2111, 2002. Stuiver, M., G. H. Denton, T. J. Hughes, and J. L. Fastook, History of the marine ice sheet in West Antarctica during the last glaciation: A working hypothesis, in The Last Great Ice Sheets, edited by G. H. Denton and T. J. Hughes, pp. 319-436, Wiley, New York, 1981.

Tushingham, A. M. and W. R. Peltier, ICE-3G: a new global model of late Pleistocene deglaciation based upon geophysical predictions of postglacial relative sea-level, J. Geophys. Res., 96, 4497-4523, 1991.

$\mathrm{Wu}, \mathrm{P}$. and W. R. Peltier, Glacial isostatic adjustment and free air gravity anomaly as a constraint on deep mantle viscosity, Geophys. J. R. Astron. Soc., 74, 377-449, 1983.

Yamada, A., K. Maruyama, O. Ootaki, A. Itabashi, Y. Hatanaka, S. Miyazaki, H. Negishi, T. Higashi, Y. Nogi, M. Kanao, and K. Doi, Analysis of GPS data at Syowa Station and IGS tracking station, Polar Geosci., 11, 1-8, 1998.

Zumberge, J. F., M. B. Heflin, D. C. Jefferson, M. N. Watkins, and F. H. Webb, Precise point positioning for the efficient and robust analysis of GPS data from large networks, J. Geophys. Res., 102, 5005-5017, 1997.

M. Ohzono (e-mail: ohzono@seis.nagoya-u.ac.jp), T. Tabei, K. Doi, K. Shibuya, and T. Sagiya 